\title{
Pengaruh Pemberian Fermentasi Kotoran Ayam Roti Afkir Dan Ampas Tahu Dalam Media Kultur Massal Terhadap Pertumbuhan Dan Kandungan Nutrisi Daphnia sp
}

\author{
Zumalallail Nailulmuna, Pinandoyo dan Vivi Endar Herawati \\ Departemen Akuakultur Jurusan Perikanan Fakultas Perikanan dan Ilmu Kelautan, \\ Universitas Diponegoro Jl. Prof. H. Sudharto, Tembalang, Semarang. Telp/Fax. +6224 7474698 \\ anshinvie@yahoo.com
}

\begin{abstract}
Daphnia sp. is one kind of natural food that has many advantages. Some advantages of Daphnia sp. is a high nutrient content, according to the size suitable for fish larvae, and the provision of Daphnia sp. in the form of life does not cause a decrease in water quality. Nutrition content on the Daphnia sp. became from the suspended organic and the bacteria which was obtained from the fertilizer that added to the culture media. This research was aimed to found out the effect of fermented quail feces, bread waste, and tofu and determine the best treatment to generate the biomass growth, and the nutrition content of the Daphnia sp.

This research used laboratory animals such as Daphnia sp. and a container of concrete tanks as many as four. The methods of this research was used experimental methods with Complete Randomize Design with 4 treatments and population count repetition as 3 times with the density of the Daphnia sp. was 100 ind./1. Treatments of this research were Tretment A (0\% chicken mannure, $50 \%$ tofu waste and $50 \%$ bread waste), B (25\% chicken mannure, $50 \%$ tofu waste and $25 \%$ bread waste), C (25\% chicken mannure, $25 \%$ tofu waste and $50 \%$ bread waste, D (50\% chicken mannure, $25 \%$ tofu waste and $25 \%$ bread waste) with the total amount of the combination was $200 \mathrm{~g} / \mathrm{l}$. Data which observed were population density, biomass, and nutrition content. The results showed that the treatment of A was the lowest population density valued $548.67 \mathrm{ind} / \mathrm{ml}$ and the highest population density was on $\mathrm{C}$ treatment with a density of 1328.67 ind / $\mathrm{ml}$ at the peak of the stationary phase. Biomass in treatment $\mathrm{C}$ resulted in 336.30 grams and the treatment $\mathrm{A}$ yield 82.64 grams, and the content of nutrients with the highest protein is found in the $\mathrm{C}$ treatment with a value of $66.80 \%$.
\end{abstract}

Keywords :Daphnia sp.;chicken manure; tofu waste; bread waste; fermentation

\begin{abstract}
Abstrak
Daphnia sp. merupakan salah satu jenis pakan alami yang memiliki banyak keunggulan.Beberapa keunggulan Daphnia sp.yaitu kandungan nutrisi yang tinggi, ukuranya sesuai dengan bukaan mulut larva ikan, serta pemberian Daphnia sp. dalam bentuk hidup tidak menyebabkan penurunan kualitas air. Kandungan nutrisi dalam tubuh Daphnia sp.berasal dari bahan organik tersuspensi dan bakteri yang diperoleh dari pupuk yang ditambahkan ke dalam media kultur.Penelitian ini bertujuan untukmengetahui pengaruh pemberian kombinasi fermentasi kotoran ayam, roti afkir dan ampas tahu serta mengetahui perlakuan terbaik untuk menghasilkan pertumbuhan, biomass, dan kandungan nutrisi Daphnia sp..

Penelitian ini menggunakan hewan uji berupa Daphnia sp. dan wadah berupa bak beton sebanyak empat buah. Metode yang digunakan dalam penelitian ini yaitu dengan metode eksperimental dengan Rancangan Acak Lengkap dengan 4 perlakuan dan pengulangan perhitungan populasi sebanyak 3 kali dengan padat penebaran Daphnia sp. yaitu 100 ind/l. Perlakuan dalam penelitian ini yaitu Perlakuan A (0\% kotoran ayam, $50 \%$ ampas tahu dan $50 \%$ roti afkir), B (25\% kotoran ayam, $50 \%$ ampas tahu dan $25 \%$ roti afkir), C (25\% kotoran ayam, $25 \%$ ampas tahu dan $50 \%$ roti afkir, D (50\% kotoran ayam, $25 \%$ ampas tahu dan $25 \%$ roti afkir) dengan Jumlah total kombinasi yaitu 200 g/l.Data yang diamati meliputi kepadatan populasi, biomass, dan kandungan nutrisi. Hasil penelitian menunjukkan bahwa pada perlakuan A memiliki tingkat kepadatan populasi terendah yaitu $548.67 \mathrm{ind} / \mathrm{ml}$ dan tingkat kepadatan populasi tertinggi terdapat pada perlakuan $\mathrm{C}$ dengan kepadatan $1328.67 \mathrm{ind} / \mathrm{ml}$ pada fase puncak stasioner. Biomass pada perlakuan C menghasilkan 336.30 gram dan pada perlakuan A menghasilkan 82.64 gram, dan kandungan nutrisi dengan protein tertinggi yaitu terdapat pada perlakuan C dengan nilai $66.80 \%$.
\end{abstract}

Kata kunci:Daphnia sp.; kotoran ayam; ampas tahu; roti afkir; fermentasi 


\section{PENDAHULUAN}

Daphnia sp. merupakan salah satu jenis pakan alami yang memiliki banyak keunggulan, sehingga sangat potensial untuk dikembangkan.Daphnia sp. biasa digunakan untuk memenuhi kebutuhan pakan larva ikan air tawar baik ikan konsumsi maupun ikan hias pada tahap pembenihan.Beberapa keunggulan Daphnia sp.yaitu kandungan nutrisi yang tinggi, ukuranya sesuai dengan bukaan mulut larva ikan, dan dapat dibudidayakan secara massal (Chasim, 2014).Selain itu pemberian Daphnia sp. hidup tidak menyebabkan penurunan kualitas air.Daphnia sp. juga memiliki kemampuan berkembangbiak dengan cepat dalam waktu yang relatif singkat, umur Daphnia betina mulai beranak antara 4-6 hari dan dapat memproduksi telur hingga 100 butir, sehingga ketersediaannya dapat terjamin sepanjang waktu. Berdasarkan keunggulan-keunggulan tersebutNutrisi yang terkandung dalam Daphnia sp. bergantung pada media kultur yang digunakan, karena sumber makanan yang akan dikonsumsi oleh Daphnia sp. terdapat pada media hidupnya. Daphnia sp. bersifat non selective filter feeder sehingga penambahan nutrisi dapat dilakukan melalui media (Jusadi et al., 2008).

Tujuan dari penelitian ini adalah untuk mengetahui pengaruh pemberian kombinasi fermentasi kotoran ayam, roti afkir dan ampas tahu dengan dosis yang berbeda dalam media kultur, serta mengetahui perlakuan terbaik untuk menghasilkan pertumbuhan, biomass, dan kandungan nutrisi Daphnia sp. Hasil penelitian diharapkan dapat diaplikasikan kepada pembudidaya ikan air tawar dengan menggunakan pupuk dengan dosis yang sesuai sebagai media untuk kultur Daphnia sp. Penelitian ini dilaksanakan pada bulan Mei hingga Juli 2016 yang bertempat di Sekertariat Asosiasi Pembudidaya dan Pedagang Ikan Hias Semarang (APPIHS), Poncol, Semarang

\section{BAHAN DAN METODE}

Hewan uji yang digunakan pada penelitian ini yaitu pakan alami berupa Daphnia sp. yang diperoleh dari alam dengan kepadatan penebaranyaitu 100 ind/l. Dasar penebaran yang dilakukan berdasarkan penelitian yang dilakukan oleh Herawatiet. al., (2015) bahwa kepadatan penebaran Daphnia sp. sebanyak 100 ind/l. Wadah yang digunakan dalam kultur masal Daphnia sp. adalah bak beton sebanyak 4 buah dengan ukuran $2 \times 1,2 \times 0,5 \mathrm{~m}$ yang diisi air sebanyak 600 liter. Media yang digunakan dalam kulturDaphnia sp. berupa pupuk organik kombinasi dari kotoran ayam, ampas tahu, dan roti afkir yang di fermentasi menggunakan bakteri probiotik.Pupuk organik yang sudah difermentasi selanjutkan dimasukan kedalam air media yang akan digunakan untuk kultur Daphnia sp..

Rancangan percobaan yang digunakan dalam penelitian ini adalah Rancangan Acak Lengkap (RAL) menggunakan 4 perlakuan dan setiap penghitungan populasi diulang sebanyak 3 kali. Jumlah total kombinasi antara kotoran ayam, ampas tahu, dan roti afkir yaitu $200 \mathrm{~g} / 1$. Perlakuan tersebut memodifikasi penelitian Herawati et al., (2016) dengan perlakuan terbaik pada $50 \mathrm{gr} / \mathrm{L}$ kotoran ayam, $100 \mathrm{gr} / \mathrm{L}$ roti afkir, $50 \mathrm{gr} / \mathrm{L}$ ampas tahu. Perlakuan dalam penelitian adalah kombinasi pupuk organik dalam media kultur dengan dosis yang berbeda yaitu:

Perlakuan A : $0 \%$ kotoran ayam, $50 \%$ ampas tahu dan $50 \%$ roti afkir;

Perlakuan B : $25 \%$ kotoran ayam, $50 \%$ ampas tahu dan $25 \%$ roti afkir;

Perlakuan C : $25 \%$ kotoran ayam, $25 \%$ ampas tahu dan $50 \%$ roti afkir;

Perlakuan D : $50 \%$ kotoran ayam, $25 \%$ ampas tahu dan $25 \%$ roti afkir;

Tahapan sebelum dilakukan penebaran pupuk organik kedalam media kultur yaitu menyiapkan semua bahan, melakukan penimbangan bahan yang akan digunakan, dan melakukan analisa nutrien pupuk organik sebelum dan setelah fermentasi. 
Tabel 1. Kandungan nutrient pupuk organik sebelum fermentasi

\begin{tabular}{lccccc}
\hline \multirow{2}{*}{ Parameter } & \multicolumn{4}{c}{ Hasil analisa sebelum fermentasi } & \multirow{2}{*}{ Metode uji } \\
\cline { 2 - 5 } & $\mathrm{A}$ & $\mathrm{B}$ & $\mathrm{C}$ & $\mathrm{D}$ & \\
\hline Nitrogen (N) & $1,54 \pm 0,06$ & $2,24 \pm 0,09$ & $2,75 \pm 0,07$ & $1,23 \pm 0,02$ & Kjeldahl \\
Phosphor (P) & $0,19 \pm 0,03$ & $0,18 \pm 0,07$ & $0,25 \pm 0,01$ & $0,23 \pm 0,03$ & AQAC 958.01.2000 \\
Kalium (K) & $0,39 \pm 0,02$ & $0,27 \pm 0,01$ & $0,27 \pm 0,01$ & $0,26 \pm 0,06$ & AQAC 958.01.2000 \\
\hline
\end{tabular}

Tabel 2. Kandungan nutrient pupuk organik sesudah fermentasi

\begin{tabular}{|c|c|c|c|c|c|}
\hline \multirow{2}{*}{ Parameter } & \multicolumn{4}{|c|}{ Hasil analisa sesudah fermentasi } & \multirow{2}{*}{ Metode uji } \\
\hline & $\mathrm{A}$ & $\mathrm{B}$ & $\mathrm{C}$ & $\mathrm{D}$ & \\
\hline Nitrogen $(\mathrm{N})$ & $2,74 \pm 0,05$ & $3,40 \pm 0,05$ & $3,84 \pm 0,03$ & $2,43 \pm 0,09$ & Kjeldahl \\
\hline Phosphor (P) & $0,27 \pm 0,02$ & $0,48 \pm 0,04$ & $0,43 \pm 0,06$ & $0,59 \pm 0,03$ & AQAC 958.01.2000 \\
\hline Kalium (K) & $0,69 \pm 0,09$ & $1,21 \pm 0,02$ & $0,89 \pm 0,08$ & $1,36 \pm 0,03$ & AQAC 958.01.2000 \\
\hline
\end{tabular}

Data yang diperoleh berdasarkan penelitian meliputi kepadatan populasi Daphnia sp., biomassa, kandungan nutrisi, dan kualitas air.

\section{Kepadatan Popupasi Daphnia sp.}

Kepadatan populasi Daphnia sp. dihitung setiap 2 hari dengan mengambil Daphnia sp. pada 3 titik sampling paling padat sebanyak $1 \mathrm{ml}$ kemudian dilakukan perhitungan jumlah Daphnia sp. pada setiap titik sampling dan dilakukan 3 kali pengulangan pada setiap titik untuk mendapatkan data yang valid.

\section{Biomassa Daphnia sp.}

Perolehan data biomass Daphnia sp. yaitu denganpenimbanganbobot pada awal penebaran dan penimbangan bobot Daphnia sp. pada akhir pemeliharaan.Penghitungan menggunakan rumus $\left(\mathrm{W}=\mathrm{Wt}-\mathrm{W}_{0}\right)$ dimana $\mathrm{W}$ adalah bobot biomass Daphnia sp. yang dihasilkan selama kultur, Wt merupakan bobot awal penebaran dan $\mathrm{W}_{0}$ adalah bobot akhir pemeliharaan. Hal tersebut bertujuan untuk mengetahui bertambahnya biomassa Daphnia sp..

\section{Kandungan Nutrisi}

Kandungan nutrisi diperoleh dari uji analisa proksimat yang meliputi Protein, karbohidrat, lemak, serat kasar, dan kadar abu. Menurut Izzah (2014) menjelaskan bahwa kandungan nutrisiDaphnia sp yang dianalisa berupa protein, karbohidrat, lemak, dan abu dalam berat kering, analisis kimia pada Daphnia sp. yang dilakukan adalah analisis proksimat.

\section{Kualitas air}

Pengukuran parameter kualitas air yang meliputi suhu, DO, dan $\mathrm{pH}$ dilakukan setiap hari. Pengukuran DO menggunakan DO meter, pengukuraan suhu menggunakan termometer dan pengukuran $\mathrm{pH}$ menggunakan $\mathrm{pH}$ tester. Pengontrolan $\mathrm{pH}$ air berkisar antara 7,5-8,0 apabila $\mathrm{pH}$ air berada dibawah 7,5 maka dilakukan penambahan kapur dolomit.

Data yang didapatkan dianalisa menggunakan Analisa ragam (ANOVA) yang terlebih dahulu dilakukan uji normalitas, uji homogenitas dan uji additivitas untuk mengetahui bahwa data bersifat normal, homogen dan aditif.Apabila diketahui terdapat pengaruh yang nyata $(P<0,05)$ atau sangat nyata $(P<0,01)$, maka dilanjutkan dengan Uji Wilayah Ganda Duncan untuk mengetahui perbedaan nilai tengah antar perlakuan dan menentukan perlakuanyang terbaik. Data kualitas air dianalisis secara deskriptif 


\section{HASIL DAN PEMBAHASAN}

\section{Kepadatan populasi Daphnia sp.}

Berdasarkan hasil penelitian yang telah dilakukan didapatkan hasil kepadatan populasi Daphnia sp. yang membentuk pola pertumbuhan populasi Daphnia sp. Hasil yang didapatkan berdasarkan data pertumbuhan populasi Daphnia sp. yang dikultur menggunakan bahan organik yang meliputi: kotoran ayam, ampas tahu, dan roti afkir pada seluruh perlakuan menunjukkan pola yang relatif sama antar perlakuan, baik yang menggunakan kotoran maupun tanpa menggunakan kotoran ayam. Hasil pengamatan pertumbuhan populasi Daphnia sp. selama 26 hari dengan periode perhitungan 2 hari sekalitersaji pada Gambar 1

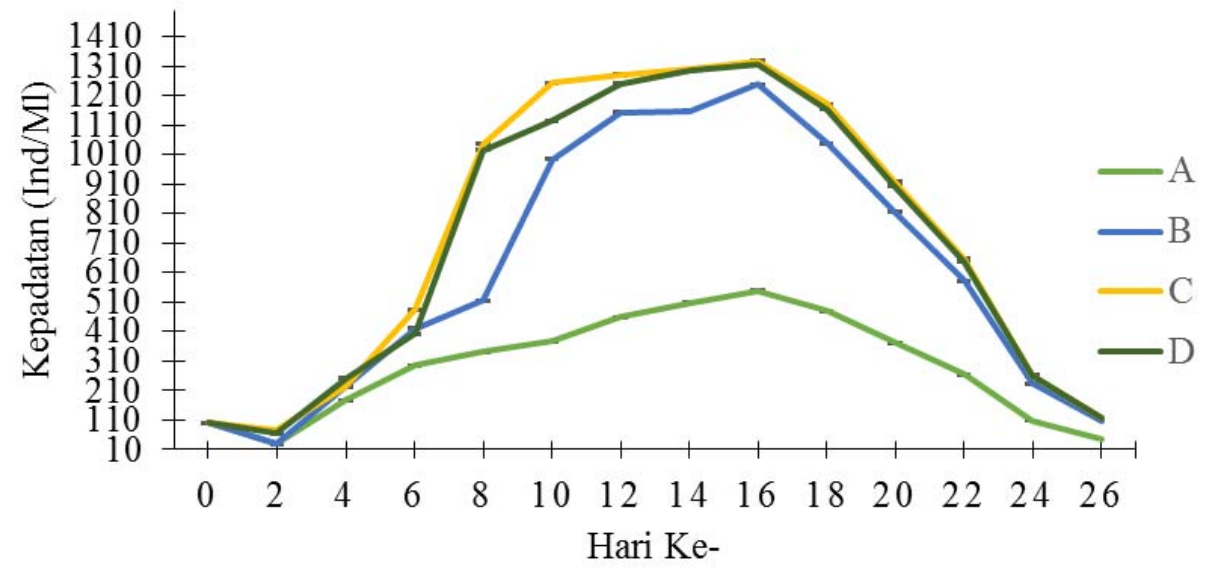

Gambar 1.Grafik Pola pertumbuhan populasi Daphnia sp

Pola pertumbuhan Daphnia sp.selama pemeliharaan membentuk kurva sigmoid.Kurva sigmoid terdiri dari fase adaptasi, fase eksponensial, fase stasioner dan fase kematian.Fase adaptasi dimulai dari hari ke-2 hingga hari ke-4 pada masing-masing perlakuan.Fase eksponensial dimulai setelah hari ke-6 pada setiap perlakuan. Fase stasioner mengalami puncak kepadatan tertinggi yg terjadi pada hari ke-16dengan perlakuan $\mathrm{C}$ memiliki jumlah populasi terpadat yaitu $1328.67 \mathrm{ind} / \mathrm{ml}$ dan perlakuan A memiliki kepadatan terendah yaitu $548.67 \mathrm{ind} / \mathrm{ml}$. Fase kematian terjadi setelah hari ke 18 pada setiap perlakuan.

\section{Biomassa Daphnia sp.}

Berdasarkan hasil penelitian yang dilakukan didapatkan hasil bobot biomass Daphnia sp.selama pemeliharaan dalam berat basah yang disajikan dalam Gambar 2 sebagai berikut. 


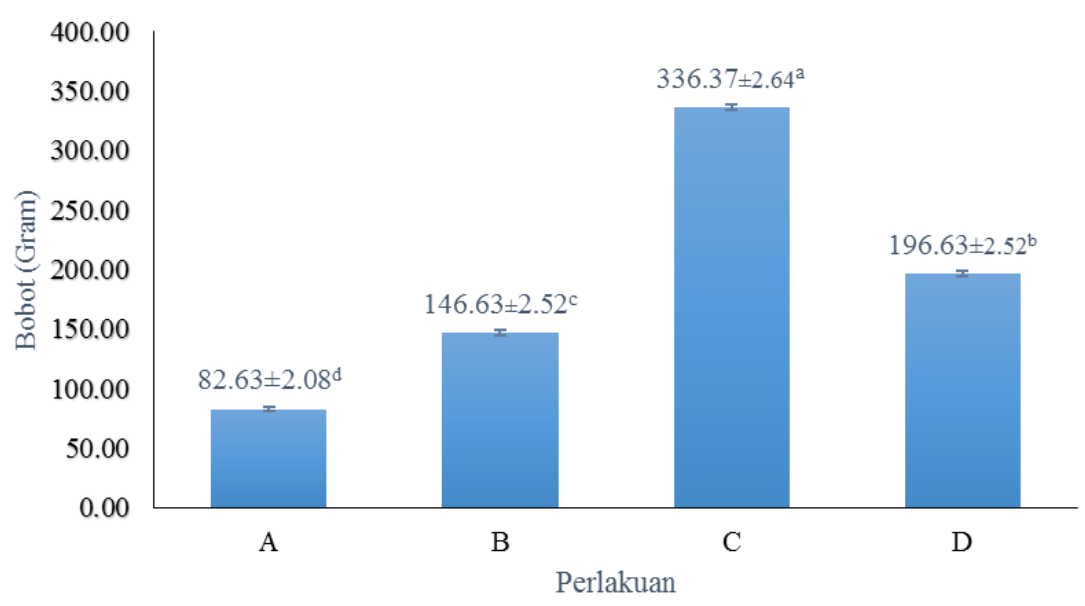

Gambar 2.Produksi biomass Daphnia sp

Berdasarkan pada hasil yang tersaji pada gambar 2, produksi biomass Daphnia sp. selama pemeliharaan berat biomass dari hasil tertertinggi hingga terendah terdapat pada perlakuan $\mathrm{C}$ dengan bobot 336.37 gram, perlakuan $\mathrm{D}$ dengan bobot 196.63 gram, selanjutnya pada perlakuan B dengan bobot 146.63 gram, dan paling rendah biomass selama pemeliharaan yaitu pada perlakuan A yang hanya mencapai bobot biomassa 82.63 gram.
Setelah dilakukan penimbangan biomass Daphnia sp. dijemur hingga kering untuk selanjutnya dilakukan analisa kandungan nutrisi Daphnia sp. .

\section{Analisa kandungan nutrisi Daphnia sp.}

Berdasarkan hasil penelitian yang dilakukan setelah didapatkan bobot biomass Daphnia sp. selanjutnya dilakukan uji analisa kandungan nutrisi yang terkandung dalam Daphnia sp.. Hasil pengujian disajikan dalam tabel 3 berikut ini :

Tabel 3. Hasil analisa kandungan nutrisi Daphnia sp.

\begin{tabular}{lcccc}
\hline \multirow{2}{*}{ Proksimat } & \multicolumn{4}{c}{ Hasil analisa proksimat Daphnia sp. } \\
\cline { 2 - 5 } & $\mathrm{A}$ & $\mathrm{B}$ & $\mathrm{C}$ & $\mathrm{D}$ \\
\hline Protein (\%) & 59,32 & 64,18 & 66,85 & 65,55 \\
Lemak (\%) & 8,16 & 8,71 & 8,84 & 8,16 \\
Serat Kasar (\%) & 2,15 & 3,05 & 2,91 & 2,59 \\
Kadar Abu (\%) & 8,43 & 8,71 & 6,11 & 6,52 \\
Kadar Air(\%) & 21,93 & 15,34 & 15,27 & 17,22 \\
\hline
\end{tabular}

Berdasarkan tabel 3. hasil analisa kandungan nutrisi Daphnia sp. didapatkan kandungan protein tertinggi terdapat pada perlakuan $\mathrm{C}$ yaitu $66,85 \%$ dan kandungan protein terendah pada perlakuan A yaitu 59,32\%.
Kandungan lemak tertinggi terdapat pada perlakuan $\mathrm{C}$ yaitu sebesar $8,84 \%$ dan terendah pada pelakuan A dan D yang memiliki persamaan nilai yaitu sebesar $8,16 \%$. Kadar abu tertinggi terdapat pada perlakuan B sebesar $8,71 \%$ dan 
terendah pada perlakuan $\mathrm{C}$ sebesar $6,11 \%$. Serat kasar tertinggi terdapat pada perlakuan B yaitu sebesar 3,05\% dan terendah pada perlakuan A yang hanya sebesar $2,15 \%$. Kadar air tertinggi terdapat pada perlakuan A yaitu sebesar 21,93\% dan kandungan kadar air terendah terendah pada perlakuan C yaitu sebesar 15,27\%.
Pengukuran kualitas air dilakukan setiap hari. Parameter yang diukur meliputi suhu, $\mathrm{pH}$, dan DO. Data pengukuran kualitas air disajikan dalam bentuk kisaran dan dibandingkan berdasarkan referensi. Data pengukuran kualitas air dapat dilihat pada tabel 4. Data pengukuran kualitas air sebagai berikut:

\section{Kualitas air}

Tabel 4. Pengukuran kualitas air

\begin{tabular}{llc}
\hline & Kisaran & Kelayakan Menurut Pustaka \\
\hline DO $(\mathrm{mg} / \mathrm{L})$ & $3,2-3,5$ & $3-4^{*}$ \\
$\mathrm{pH}$ & $7,3-8,6$ & $6,5-9,5^{* *}$ \\
$\mathrm{Suhu}\left({ }^{0} \mathrm{C}\right)$ & $26-31$ & $22-31^{*}$ \\
\hline
\end{tabular}

Keterangan : $\quad *($ Mubarak, 2009)

** (Mufidah, 2009)

Fase adaptasi merupakan fase penyesuaian Daphnia sp. terhadap media kultur. Fase adaptasi yang terjadi selama penelitian berlangsung pada hari ke-0 hingga hari ke-4 pada seluruh perlakuan. Hal ini terjadi karena adanya faktor yang mempengaruhi proses adaptasi yang meliputi penyesuaian terhadap lingkungan maupun penyesuaian terhadap kandungan bahan organik yang terdapat pada media kultur Daphnia sp.. Pertumbuhan lag phase merupakan pertumbuhan fase awal dimana penambahan kelimpahan individu yang terjadi masih rendah. Menurut Firdaus (2004) menyatakan bahwa terjadinya penyesuaian terhadap media kultur dan kepekatan dalam media kultur mempengaruhi cepat atau lambatnya pertumbuhan Daphnia sp.. Hasil penelitian menunjukkan bahwa jumlah kepadatan Daphnia sp. pada fase adaptasi antar perlakuan berbeda-beda yaitu pada perlakuan A sebesar $158.78 \mathrm{ind} / \mathrm{ml}$, perlakuan B sebesar $216.33 \mathrm{ind} / \mathrm{ml}$, perlakuan C $253 \mathrm{ind} / \mathrm{ml}$, dan perlakuan D 230.89 ind $/ \mathrm{ml}$. Kepadatan populasi Daphnia sp. pada perlakuan A merupakan kepadatan terendah dari hasil perlakuan yang lainnya, sedangkan pada perlakuan $\mathrm{C}$ merupakan kepadatan populasi tertinggi. Perbedaan kepadatan populasi ini diduga karena adanya perbedaan dalam dosis bahan organik yang digunakan dalam media kultur dan kandungan nutrisi yang berbeda sehingga menyebabkan kelimpahan plankton dalam media kultur berbeda, karena plankton dan detritus merupakan makanan untuk Daphnia sp.. Kelimpahan plankton pada fase adaptasi dalam media kultur pada perlakuan A hanya berjumlah $4.247 \mathrm{sel} / \mathrm{ml}$ sedangkan pada perlakuan $\mathrm{C}$ berjumlah $6.767 \mathrm{sel} / \mathrm{ml}$. Jenis fitoplankton yang mendominasi pada media kultur berasal dari family Clorophyceae.Di alam Daphnia sp. mengkonsumsi pakan berupa bakteri, fitoplankton, ciliata, dan detritus (Darmawan, 2014). Pernyataan tersebut juga dijelaskan oleh Sarmudianto et al., (2015) alga dan protozoa merupakan makanan utama Daphnia sp., bakteri dan fungi menduduki urutan teratas dari nilai nutrisi baginya dengan jenis makanan ini, Daphnia sp dapat hidup dan berkembang biak.

Fase eksponensial merupakan fase perbanyakan individu dalam jangka waktu tertentu karena adanya proses reproduksi. Fase eksponensial pada perlakuan $\mathrm{A}, \mathrm{C}$, dan D terjadi pada hari ke-8 dengan kepadatan pada perlakuan $\mathrm{A}$ sebanyak $341.33 \mathrm{ind} / \mathrm{ml}$, perlakuan $\mathrm{C}$ sebanyak $1046.33 \mathrm{ind} / \mathrm{ml}$, perlakuan D sebanyak 1027.67 ind $/ \mathrm{ml}$, sedangkan pada perlakuan B terjadi pada hari ke-10 dengan kepadatan sebanyak 994.67 ind $/ \mathrm{ml}$. Perbedaan pencapaian fase eksponensial diduga karena pengaruh lingkungan media kultur terutama dalam kualitas air. Fase eksponensial perlakuan B dimulai setelah hari ke-8 diduga 
disebabkan oleh penurunan $\mathrm{pH}$ air media kultur yang mencapai 7.3. Nilai tersebut merupakan kisaran terendah selama penelitian berlangsung.Kestabilan pH dalam media pemeliharaan Daphnia sp. dapat ditingkatkan dengan penambahan dolomit (Mubarak, 2009). Faktor lain yang diduga mempengaruhi perbedaan pencapaian fase eksponensial dijelaskan oleh Mubarak (2009) salah satu faktor yang mempengaruhi populasi Daphnia sp. yaitu pakan. Ketersediaan pakan memengaruhi pertumbuhan dan merupakan faktor penting untuk kemampuan reproduksi (Putri et al., 2014).Media kultur yang meliputi kotoran ayam, ampas tahu, dan roti afkir digunakan sebagai media merupakan sumber makanan bagi plankton untuk tumbuh dan berkembang sebagai pakan Daphnia sp.. Kandungan N, P, K dan nutrisi dari kotoran ayam, ampas tahu, dan roti afkir secara tidak langsung diubah menjadi asam amino, protein dan bahan lain terlebih dahulu untuk dapat dimanfaatkan sebagai pakan. Semakin tinggi populasi fitoplankton yang ada dalam media budidaya maka ketersediaan pakan bagi Daphnia sp. semakin melimpah sehingga mencukupi kebutuhan energi untuk pertumbuhan Daphnia sp. yang ditandai dengan peningkatan populasi (Wibowo, 2014).

Fase stasioner merupakan fase yang terjadi setelah fase eksponensial, Fase ini ditandai dengan tidak adanya pertambahan jumlah pertumbuhan Daphnia sp., ataupun terjadinya penurunan jumlah pertumbuhan, sehingga penambahan dan pengurangan jumlah relatif sama. Fase stasioner umumnya menggambarkan puncak pertumbuhan populasi hingga terjadinya penurunan jumlah populasi secara drastis yang diakibatkan terjadinya kematian massal (Darmawan, 2014).Puncak fase stasioner terjadi pada hari ke-16 dengan jumlah kepadatan pada perlakuan A sebanyak 548.67 ind $/ \mathrm{ml}$, perlakuan B sebanyak $1249 \mathrm{ind} / \mathrm{ml}$, perlakuan C sebanyak $1328.67 \mathrm{ind} / \mathrm{ml}$, dan perlakuan D sebanyak $1315.67 \mathrm{ind} / \mathrm{ml}$. Berdasarkan hasil penelitian tersebut tingkat pertumbuhan tertinggi terdapat pada perlakuan C. Hal ini diduga karena adanya pengaruh dari tingginya nutrient yang terkandung dalam media kultur Daphnia sp.. Kandungan unsur N yang terdapat pada media kultur perlakuan $\mathrm{C}$ yaitu 3,84 . Jumlah tersebut merupakan jumlah tertinggi bila dibandingkan dengan kandungan $\mathrm{N}$ pada perlakuan lainnya. Kandungan $\mathrm{N}$ pada perlakuan A sebesar 2,74, perlakuan B sebesar 3,40, dan perlakuan D sebesar 2,43. Kandungan N, P, dan K inilah yang nantinya akan dimanfaatkan oleh fitoplankton sebagai media hidup. Kepadatan plankton yang diamati pada fase ini berjumlah $13.434 \mathrm{sel} / \mathrm{ml}$ pada perlakuan A, $30.581 \mathrm{ind} / \mathrm{ml}$ pada perlakuan B, $33.740 \mathrm{ind} / \mathrm{ml}$ pada perlakuan $\mathrm{C}$ dan $33.389 \mathrm{ind} / \mathrm{ml}$ pada perlakuan D. Unsur hara seperti N, P, dan $\mathrm{K}$ merupakan nutrien yang digunakan sebagai media hidup fitoplankton yang berfungsi sebagi pakan untuk Daphnia sp.. Hal ini dijelaskan dalam Syahendra (2016) bahwa pakan alami dapat tumbuh dalam berbagai media yang mengandung cukup unsur hara seperti $\mathrm{N}, \mathrm{P}$, dan $\mathrm{K}$ serta unsur mikro lainnya. Kepadatan plankton pada perlakuan A lebih sedikit dibandingkan dengan perlakuan lainnya. Hal ini diduga karena adanya pengaruh pada pemberian kotoran ayam pada perlakuan B, C, dan D. Pernyataan tersebut sesuai dengan Putri et al., (2014) yang menerangkan bahwa faktor pemberian bahan organik berupa kotoran ayam memiliki persentase nilai $\mathrm{N}$ organik yang tinggi jika dibandingkan dengan perlakuan tanpa menggunakan kotoran ayam. Kandungan nutrisi dalam media kultur yang kurang terpenuhi dapat mengakibatkan terjadinya kompetisi makanan antar individu karena tingkat pemanfaatan pakan yang dikonsumsi oleh Daphnia sp. dapat mempengaruhi kelimpahan dan pertumbuhanya (Izzah, 2014). Memasuki fase stasioner, laju pertumbuhan populasi Daphnia sp. mulai mengalami penurunan akibat ketersediaan pakan yang terdapat dalam media budidaya tidak mampu mencukupi kebutuhan sejumlah Daphnia sp. yang terdapat dalam wadah budidaya untuk dapat tumbuh secara optimal (Darmawan, 2014).

Fase kematian (Death phase) terjadi setelah hari ke-16 pada seluruh perlakuan. Jumlah kepadatan populasi Daphnia sp. berdasarkan histogram selama fase kematian jumlah yang tersisa pada perlakuan A yaitu sebesar 293.00 ind $/ \mathrm{ml}$, perlakuan B sebesar $534.44 \mathrm{ind} / \mathrm{ml}$, perlakuan C sebesar $603.67 \mathrm{ind} / \mathrm{ml}$, dan perlakuan D sebesar $593.11 \mathrm{ind} / \mathrm{ml}$. Firdaus (2004) menyatakan bahwa penyebab terjadinya penurunan populasi Daphnia sp disebabkan karena semakin berkurangnya bahan organik terlarut. Kematian ini 
terjadi sebagai dampak tingginya densitas Daphnia sp.pada media budidaya yang mengakibatkan terjadinya persaingan untuk terus bertahan hidup. Hal ini ditandai dengan penurunan pada grafik pertumbuhan Daphnia sp..Pada fase ini, jumlah fitoplankton dan material organik sebagai pakan yang tersedia pada media terlalu sedikit dan tidak mencukupi kebutuhan dari populasi Daphnia sp. yang sangat melimpah sehingga menyebabkan penurunan laju pertumbuhan dan terjadi kompetisi dalam memperoleh makanan (Darmawan, 2014).Penelitian yang dilakukan Izzah (2014) menyebutkan bahwa fase kematian disebabkan oleh beberapa faktor diantaranya adalah temperatur tinggi, kurangnya nutrisi dalam perairan, perubahan $\mathrm{pH}$, kontaminasi, serta berkurangnya proses fotosintesis. Ketersediaan nutrisi yang semakin berkurang setiap hari akan menyebabkan kematian bagi bakteri sehingga dengan adanya toksik yang dihasilkan dari kematian ini juga akan berpengaruh terhadap kehidupan Daphnia sp. Fase akhir budidaya Daphnia sp. mengalami penurunan jumlah populasi, hal ini diduga disebabkan oleh jumlah nutrien yang terkandung didalam media kultur telah berkurang karena telah dimanfaatkan oleh fitoplankton (Wibowo, 2014).

Biomassa Daphnia sp. didapatkan dari hasil perhitungan bobot akhir pada saat pemanenan dikurangi bobot awal pada saat penebaran. Produksi biomass Daphnia sp. tertinggi terdapat pada perlakuan $\mathrm{C}$ sebesar 336.37 gram, selanjutnya berat biomass pada perlakuan D dengan bobot biomass yang mencapai 196.63 gram, selanjutnya pada perlakuan B dengan bobot yaitu 146.63 gram, dan paling rendah biomass selama pemeliharaan yaitu pada perlakuan A yang hanya mencapai bobot biomassa 82.63 gram. Menurut Krettiawan (2011) menyatakan bahwa Perbedaan jumlah populasi di saat panen tentu berkaitan erat dengan kandungan nutrisi dari pakan yang diberikan. Hasil terbaik pada perlakuan $\mathrm{C}$ diduga karena adanya pertambahan nilai nutrisi yang dihasilkan dari proses fermentasi. Berdasarkan penelitian yang dilakukan oleh Sitohang(2012) menyebutkan bahwa proses fermentasi pupuk organik oleh bakteri probiotikmeningkatkan kandunga nutrisi pupuk organik sebagai persyaratan nutrisi lebih baik untuk pertumbuhan biomassa Daphnia sp.. Hal ini sesuai dengan data analisa kandungan nutrient bahwa terjadi peningkatan kandungan $\mathrm{N}, \mathrm{P}$, dan $\mathrm{K}$ dalam pupuk organik dari sebelum fermentasi hingga setelah fermentasi. Kenaikan kandungan $\mathrm{N}$ dalam perlakuan $\mathrm{C}$ sebesar 1,09. Kenaikan kandungan $\mathrm{P}$ sebesar 0,18, dan kenaikan kandungan $\mathrm{K}$ sebesar 0,62 . Bobot biomass terendah terdapat pada perlakuan A. Hal ini diduga karena rendahnya kandungan nutrient yang terdapat dalam media kultur yang mengakibatkan minimnya pertumbuhan fitoplankton yang menjadi sumber makanan Daphnia sp. sehingga mempengaruhi dalam proses pertumbuhan dan reproduksi. Sumber makanan sangat penting dalam kultur Daphnia sp.. Hal ini dijelaskan dalam Sitohang (2012) karena fungsi makanan memiliki peranan penting sebagai nutrisi dalam pertumbuhan biomassa Daphnia sp. dimana berbagai aktifitas kimiawi dan fisiologis terjadi didalam tubuh individu Daphnia sp. seperti pertambahan ukuran panjang, berat, dan pergantian kulit. Kualitas dan jumlah pupuk yang diberikan pada media berpengaruh terhadap jumlah makanan yang ada pada media (Pursetyo et. al., 2011).Jumlah pupuk yang diberikan selama pemeliharaan menyebabkan perbedaan ketinggian substrat sehingga dapat mempengaruhi jumlah populasi dan biomassa.

Kandungan nutrisi yang terdapat pada Daphnia sp. hasil penelitian menunjukkan bahwa adanya perbedaan pada masing-masing perlakuan. Perlakuan $\mathrm{C}$ dengan kandungan protein tertinggi yaitu $66,85 \%$ dan terendah pada perlakuan $\mathrm{A}$ $59,32 \%$ menunjukkan bahwa adanya perbedaan kandungan protein antar perlakuan. Perbedaan kandungan nutrisi yang terdapat pada Daphnia sp. diduga karena adanya perbedaan pada komposisi antar perlakuan dimana antar perlakuan tersebut menghasilkan kandungan nutrient yang berbedabeda.Kandungan nutrient pada perlakuan $\mathrm{C}$ memiliki kandungan $\mathrm{N}$ tertinggi yaitu 3,84 hal ini merupakan faktor yang diduga mempengaruhi kandungan nutrisi pada Daphnia sp.. Pernyataan tersebut juga dijelaskan dalam penelitian Herawati dan Agus (2014) yang menyatakan bahwa tingginya kandungan protein dan rendahnya kandungan lemak dalam penelitian dikarenakan nutrient yang ada dalam media kulturDaphnia sp. 
tersebut, dimana semakin tinggi kandungan nitrat dan fosfat maka semakin tinggi kandungan proteinnya. Winarlin et al. (2010), menyatakan bahwa $\mathrm{N}$ adalah unsur hara esensial yang berperan dalam pembentukan asam amino, protein, dan senyawa lainnya. Unsur yang diperlukan mikroalga dalam jumlah besar adalah karbon, nitrogen, fosfor, natrium, dan kalsium.Pakan alami dapat tumbuh dalam berbagai media yang mengandung cukup unsur hara seperti $\mathrm{N}, \mathrm{P}, \mathrm{K}$ dan unsur mikro lainnya.Kandungan lemak tertinggi terdapat pada perlakuan C yaitu sebesar $8,84 \%$ dan terendah pada perlakuan A dan D yang memiliki nilai yang sama yaitu $8,16 \%$. Perlakuan C menggunakan komposisi 25\% kotoran ayam, 50\% roti afkir, dan 25\% ampas tahu. Kandungan lemak yang tinggi diduga karena kandungan lemak yamg berasal dari roti afkir yang tinggi.Gaol et al., (2015) menyatakan bahwa kandungan lemak kasar dalam roti afkir 13,42\% lebih tinggi dibandingkan dengan kandungan protein pada roti afkir yang hanya $10,25 \%$. Perlakuan D memiliki kandungan lemak yang rendah diduga karena komposisi pupuk organik pada media kultur yang digunakan memiliki kandungan lemak yang rendah seperti yang dijelaskan oleh Gunawati (2000) dalam penelitiannya yaitu kandungan gizi kotoran ayam adalah sebagai berikut : protein $11,25 \%$, lemak $0,78 \%$, serat kasar $4,71 \%$, air $0 \%$, dan kadar abu $54,2 \%$. Kotoran ayam mengandung protein $12,27 \%$, lemak $0,35 \%$ dan karbohidrat 29,84\% (Fajri, 2014). Berdasarkan pernyataan tersebut kotoran ayam hanya memiliki kandungan lemak yang rendah berkisar antara $0,35-0,78 \%$.

Serat kasar tertinggi dimiliki oleh perlakuan B dengan komposisi $25 \%$ kotoran ayam, $50 \%$ ampas tahu dan $25 \%$ roti afkir yang mendapat nilai sebesar 3,05\%, sedangkan kandungan serat kasar terendah terdapat pada perlakuan A dengan komposisi $0 \%$ kotoran ayam, $50 \%$ ampas tahu dan $50 \%$ roti afkir yang memiliki nilai sebesar 2,15\%. Kadar abu tertinggi terdapat pada perlakuan B yang memiliki nilai sebesar $8,71 \%$ dan terendah pada perlakuan $\mathrm{C}$ dengan nilai sebesar $6,11 \%$. Kadar air tertinggi terdapat pada perlakuan A yaitu sebesar $21,93 \%$ dan terendah pada perlakuan C sebesar $15,27 \%$. Kadar air yang tinggi diduga karena kurangnya tingkat kekeringan pada tubuh Daphnia sp. pada proses pengeringan sehingga menyebabkan masih ada kandungan air yang terdapat pada Daphnia sp. hingga pada saat proses analisa proksimat. Menurut Fajri (2014), Ampas tahu mengandung protein yaitu $21,91 \%$, karbohidrat $69,41 \%$ dan lemak $2,71 \%$. Sedangkan roti afkir mengandung protein kasar $10,25 \%$, serat kasar $12,04 \%$, lemak kasar 13,42\%, kalsium $0,07 \%$, phospor $0,019 \%$, air $6,91 \%$ dan abu $0,80 \%$ (Gaol et al., 2015).

Menurut Darmawan (2014), pola pertumbuhan Daphnia sp. ini dipengaruhi oleh beberapa faktor, antara lain kondisi fisik perairan, jenis pakan,dan konsentrasi pakan. Ketika ketiga faktor tersebut mendukung, maka laju pertumbuhan Daphnia sp.akan berlangsung lebih cepat dan menghasilkan puncak populasi yang lebih banyak. Sedangkan menurut Uttarini (20012) menyatakan bahwa Daphnia sp. tumbuh baik pada perairan dengan $\mathrm{pH}$ 6,5-9. DO dalam kisaran yang baik untuk pertumbuhan Daphnia sp. yaitu berkisar 3,40 ppm - 6,00 ppm. Daphnia sp. diketahui toleran dengan kadar oksigen rendah. Untuk dapat hidup dengan baik Daphnia $s p$. memerlukan oksigen terlarut yang cukup besar yaitu diatas 3,5 ppm.Sedangkan menurut mokoginta (2003) menyebutkan bahwaParameter kualitas air yang meliputi suhu $22^{\circ} \mathrm{C}-32^{\circ} \mathrm{C}, \mathrm{pH} 6$ - 8, oksigen terlarut $>3,5 \mathrm{ppm}$ dan kandungan amonia antara $0,35 \mathrm{ppm}-0,61 \mathrm{ppm}$. Selama budidaya Daphnia sp. berada pada kisaran optimal, sehingga tidak berpengaruh pada pertumbuhan Daphnia sp.. Kualitas air selama penelitian masih dalam kisaran yang dapat ditoleransi oleh Daphnia sp. karena media pemeliharaan selama penelitian memiliki kandunga DO sebesar 3,2-3,5mg/L, $\mathrm{pH}$ sebesar 7,3-8,6, dan Suhu sebesar $26-31^{\circ} \mathrm{C}$. Suhu merupakan faktor abiotik yang mempengaruhi peningkatan dan penurunan aktivitas organisme seperti reproduksi, pertumbuhan dan kematian Di luar kisaran suhu optimum, Daphnia spp. cenderung dorman (tidak melakukan reproduksi). Daphnia spp. hidup pada kisaran suhu $22-31^{\circ} \mathrm{C}$. Kisaran suhu tersebut merupakan kisaran suhu optimal bagi pertumbuhan dan perkembangan Daphnia sp.. Oksigen terlarut merupakan faktor yang sangat penting dalam perairan, terutama untuk proses respirasi bagi sebagian organisme air Kelarutan oksigen dipengaruhi oleh suhu. Nilai suhu berbanding terbalik dengan konsentrasi 
oksigen terlarut. Semakin tinggi suhu maka kadar oksigen terlarut semakin rendah, begitupun sebaliknya. Konsentrasi oksigen terlarut yang optimal untuk kultur Daphnia spp. yaitu $>3 \mathrm{mg} / \mathrm{l}$. Oksigen terlarut dapat ditingkatkan melalui penggunaan aerasi dan bak pemeliharaan yang diletakkan di luar ruangan, sehingga sirkulasi oksigen dapat berjalan dengan baik, dari aerasi maupun difusi udara. Perlakuan pemberian dolomit, $\mathrm{pH}$ selama pemeliharaan berada pada kisaran optimum pertumbuhan Daphnia spp., yaitu 7,1-7,5 (Mubarak, 2009)

\section{KESIMPULAN}

\section{Kesimpulan}

Kesimpulan yang dapat diambil berdasarkan hasil penelitian yang telah dilakukan adalah sebagai berikut :

1. Pemberian kombinasi fermentasi kotoran ayam, roti afkir dan ampas tahu dengan dosis yang berbeda dalam media kultur memberikan pengaruh yang sangat nyata $(\mathrm{P}<0,05)$ terhadap pertumbuhan, biomass, dan kandungan nutrisi Daphnia sp.

2. Perlakuan $\mathrm{C}$ dengan kombinasi fermentasi 25 $\%$ kotoran ayam, $25 \%$ ampas tahu dan $50 \%$ roti afkir merupakan perlakuan terbaik untuk menghasilkan pertumbuhan, biomass, dan kandungan nutrisi Daphnia sp. dari hasil kultur.

\section{Saran}

Berdasarkan penelitian yang telah dilakukan, saran yang dapat disampaikan adalah pemberian kombinasi fermentasi $25 \%$ kotoran ayam, $25 \%$ ampas tahu dan $50 \%$ roti afkir merupakan dosis yang dianjurkan dalam pola pertumbuhan, biomass, dan kandungan nutrisi Daphnia sp.

\section{UCAPAN TERIMAKASIH}

Terima kasih penulis ucapkan kepada Bapak Edi Irianto yang telah membantu selama penelitian berlangsung dan semua pihak yang telah membantu mulai dari persiapan penelitian, terlaksananya penelitian sampai terselesaikannya makalah seminar ini

\section{DAFTAR PUSTAKA}

Chasim, N. 2014. Optimalisasi Pertumbuhan dan Kelulushidupan Larva Ikan Nila (Oreochromis Niloticus) Dengan Pemberian Pakan Daphnia Sp. yang Dikultur Massal Menggunakan Pupuk Organik yang Difermentasi Em4. [Skripsi]. Fakultas Perikanan dan Ilmu Kelautan. Universitas Diponegoro. Semarang. $78 \mathrm{hlm}$.

Darmawan, J. 2014. Pertumbuhan Populasi Daphnia sp. Pada Media Budidaya Dengan Penambahan Air Buangan Budidaya Ikan Lele Dumbo (Clarias gariepinus). Berita Biologi. Balai Penelitian Pemuliaan Ikan Sukamandi. Subang. 13(1) ; 57-63

Fajri, W. N. 2014. Pengaruh Penambahan Kotoran Ayam, Ampas Tahu Dan Tepung Tapioka Dalam Media Kultur Terhadap Biomassa, Populasi dan Kandungan Nutrisi Cacing Sutera (Tubifex sp.). Journal of Aquaculture Management and Technology. 3(4); 101108

Firdaus, M. 2004. Pengaruh Beberapa Cara Budidaya Terhadap Pertumbuhan Populasi Daphnia sp. [Skripsi]. Program Studi Budidaya Perairan Fakultas Perikanan dan Ilmu Kelautan Institut Pertanian Bogor. 47 hlm.

Gaol, S. E. L., Lisnawaty S., dan Iis Y. 2015. Substitusi Ransum Jadi dengan Roti Afkir Terhadap Performa Burung Puyuh (Coturnix coturnix japonica) Umur Starter Sampai Awal Bertelur. Jurnal Ilmu Hewani Tropika. 4(2):61-65

Gunawati, R.C. 2000. Pengaruh Konsentrasi Kotoran Puyuh yang Berbeda terhadap Pertumbuhan Populasi dan Biomassa Daphnia sp. [Skripsi]. Fakultas Perikanan dan Ilmu Kelautan Institut Pertanian Bogor, Bogor, $52 \mathrm{hlm}$.

Herawati, V.E. dan M. Agus. 2014. Analisis Pertumbuhan Dan Kelulushidupan Larva Lele (Clariasgariepenus) Yang Diberi Pakan Daphnia sp. Hasil Kultur Massal Menggunakan Pupuk Organik Difermentasi. Journal of Aquaculture Management and Technology. (26): 1-11.

Herawati, V.E., Johannes H., Pinandoyo.,. Ocky K.R. 2015. Growth and Survival Rate of 
Tilapia (Oreochromis niloticus) Larvae Fed by Daphnia magna Cultured With Organic Fertilizer Resulted From Probiotic Bacteria Fermentation. HAYATI Journal of Biosciences. (30): 1-5

Herawati, V. E., Ristiawan, A. N., Johannes, H. danOcky, K. 2016. Profile of amino acids, fatty acids, proximate composition and growth performance Tubifextubifex culture with different animal wastes and probiotic bacteria. AACL Bioflux. 9 (3). DIPA. 023.05.02

Izzah, N. Suminto, dan V.E. Herawati.2014. Pengaruh Bahan Organik Bekatul dan Bungkil Kelapa Melalui Proses Fermentasi Bakteri Probiotik Terhadap Pola Pertumbuhan dan Produksi Biomassa Daphnia sp. Journal of Aquaculture Management and Technology., 3(2): 44-52.

Jusadi, D. 2008. Kadar Vitamin C Dalam Tubuh Daphnia sp. yang Diperkaya Dengan Vitamin C Pada Lama Waktu Pengkayaan yang Berbeda. Jurnal Akuakultur Indonesia. 7(1):11-17.

Krettiawan, H. 2011. Minimasi Limbah Padat Budidaya Ikan Nila (Oreochromis niloticus) Melalui Produksi Daphnia sp.. [Thesis]. Sekolah Pasca Sarjana, Institut Pertanian Bogor. Bogor. $83 \mathrm{hlm}$

Mokoginta, I. 2003. Budidaya Daphniasp. Direktorat Menengah Kejuruan. Direktorat Jenderal Pendidikan dasar dan Menengah. Jurnal Akuakultur Indonesia. 2(1): 7-11.

Mubarak, A.S. 2009. Pemberian Dolomit Pada Kultur Daphnia sp. Sistem Daily Feeding Pada Populasi Daphnia sp. dan Kestabilan Kualitas Air. Jurnal Ilmiah Perikanan dan Kelautan. 1(1): 67-72.

Mufidah, N. B. W. 2009. Pengkayaan Daphnia Spp. Dengan Viterna Terhadap Kelangsungan Hidup Dan Pertumbuhan Larva Ikan Lele Dumbo (Clarias gariepinus) . Jurnal Ilmiah Perikanan dan Kelautan., 1 (1): 59-65.

Pursetyo, K. T., Woro. H. S., dan Shofy, M. A, 2011. Pengaruh Pemupukan Ulang Kotoran Ayam Kering Terhadap Populasi Cacing
Tubifex tubifex. Jurnal Ilmiah Perikanan dan Kelautan. 3(2) ; 177-182

Putri, D.S., Eddy, S,. dan Daniel, D. 2014. Pemanfaatan Kotoran Ayam Fermentasi dan Limbah Budidaya Lele pada Budidaya Cacing Sutra dengan Sistem Resirkulasi. Jurnal Akuakultur Indonesia. 13 (2). 132 139

Sarmudianto, E., Rosmawati ., Muarif. 2015. Peningkatan Kadar Asamlemak Omega 3 Pada Daphnia sp Dengan Pengkayaan Minyak Ikan. Jurnal Mina Sains. Jurusan Perikanan Fakultas Pertanian Universitas Djuanda Bogor. 1(1). 1-5

Sitohang, R. V. Titin, H. dan Walim, L. 2012. Pengaruh Pemberian Dedak Padi Hasil Fermentasi Ragi (Saccharomyces cerevisiae) Terhadap Pertumbuhan Biomassa Daphnia sp. Jurnal Perikanan dan kelautan. Unpad. 3(1). 65-72

Syahendra, F., Johannes H., Vivi. E. H. 2016. Pengaruh Pengkayaan Bekatul dan Ampas Tahu Dengan Kotoran Burung Puyuh yang Difermentasi Dengan Ekstrak Limbah Sayur Terhadap Biomassa dan Kandungan Nutrisi Cacing Sutera (Tubifex sp.). Journal of Aquaculture Management and Technology., 5(1); 35-44

Utarini, D. R. 2012.Pertumbuhan Populasi Daphnia sp pada Media Kombinasi Kotoran Puyuh dan Ayam dengan Padat Tebar Awal Berbeda. Prosiding Seminar Nasional Pengembangan Sumber daya Pedesaan dan Kearifan Lokal Berkelanjutan II .Hal 46-52

Wibowo, A. 2014. Pemanfaatan Kompos Kulit Kakao (Theobroma cacao) Untuk Budidaya Daphnia sp.. e-Jurnal Rekayasa dan Teknologi Budidaya Perairan. 2 (2): 227232

Winarlin., A. Widiyanti, Kusdiarti dan Nuryadi. 2010. Pemanfaatan Limbah Budidaya Akuaponik untuk Produksi Pakan Alami Moina sp.. Prosiding Forum Inovasi Teknologi Akuakultur. 675-680 hlm.. 
Zumalallail Nailulmuna, Pinandoyo dan Vivi Endar Herawati 